\title{
Kvalitativno istraživanje stavova o starenju i potrebama osoba starije životne dobi u Gradu Rijeci: javnozdravstveni i bioetički aspekti
}

\section{Qualitative research of attitudes about aging and the needs of elderly people in Rijeka: public health and bioethical aspects}

\author{
Vanja Vasiljev Marchesi ${ }^{1 *}$, Aleksandar Racz ${ }^{2}$, Lovorka Bilajac ${ }^{1}$, Darko Roviš ${ }^{1}$, Tomislav Rukavina ${ }^{1}$
}

\begin{abstract}
Sažetak: Cilj: Cilj rada je utvrditi specifičnosti i stvarne potrebe, kao i mogućnosti za unaprjeđenje skrbi za starije osobe na području Grada Rijeke, oslanjajući se prvenstveno na javnozdravstvene i bioetičke aspekte. Ispitanici i metode: Ispitanici su podijeljeni u tri skupine: osobe starije životne dobi te formalni i neformalni pružatelji skrbi s područja Grada Rijeke. U svakoj skupini provedena je kvalitativna metoda fokus-grupe prema unaprijed određenom protokolu. Istraživanje je provedeno tijekom 2015. godine, a obuhvatilo je ukupno 40 ispitanika: osobe starije životne dobi $(N=12)$, formalni pružatelji skrbi $(N=14)$ i neformalni pružatelji skrbi ( $N=14)$. Rezultati: Dobiveni rezultati prikazani su u objedinjenim kategorijama za odgovarajuće tematske cjeline: percepcija starije dobi, očekivanja i potrebe, korištenje lijekova, organizacija zdravstvene skrbi, korištenje modernih tehnologija te unaprjeđenje zdravlja. Rezultati su pokazali da postoji potreba razvijanja infrastrukture i metoda samopomoći u zajednici s ciljem unaprjeđenja kvalitete života osoba starije životne dobi i produljenja samostalnosti. Zaključci: Rezultati ukazuju na potrebu integracije zdravstvene i socijalne skrbi uz podršku lokalne zajednice Grada Rijeke s posljedičnim smanjenjem troškova skrbi i unaprjeđenjem kvalitete života i produljenja samostalnosti osoba starije životne dobi.
\end{abstract}

Ključne riječi: bioetika; fokus-grupe; pružatelji skrbi; starenje
${ }^{1}$ Katedra za socijalnu medicinu i epidemiologiju, Medicinski fakultet, Sveučilište u Rijeci, Rijeka

${ }^{2}$ Zdravstveno veleučilište u Zagrebu, Zagreb

\begin{abstract}
Aim: The aim of this study was to determine the specificities and real needs as well as the possibilities for care improvement of elderly in the City of Rijeka primarily through public health and bioethics perspectives. Subjects and methods: The examinees were divided into three groups: elderly, and formal and informal caregivers from the City of Rijeka. In each group, a qualitative focus group method was performed according to a predetermined protocol. The study was conducted during 2015 and included a total number of 40 examinees: elderly $(N=12)$, formal caregivers $(N=14)$ and informal caregivers $(N=14)$. RESULTS: Study results are shown in integrated categories for particular thematic issues: perception of ageing, expectation and needs, usage of medicines, organization of health care, usage of modern technologies, and health promotion. Results have shown that there is a need for further development of infrastructure self-management methods in community in order to improve the quality of life and prolongation of independence of the elderly. Conclusions: The results indicate the need for integration of health and social care with the support of local community of the City of Rijeka with consequent reduction of care costs and the improvement of the quality of life and extended independence of the elderly.
\end{abstract}

Key words: ageing; bioethics; caregivers; focus groups
*Dopisni autor:

Izv. prof. dr. sc. Vanja Vasiljev Marchesi Katedra za socijalnu medicinu i epidemiologiju, Sveučilište u Rijeci, Medicinski fakultet

Braće Branchetta 20, 51000 Rijeka e-mail:vanjav@uniri.hr 


\section{UVOD}

Starenje stanovništva demografski je izazov ne samo razvijenih zemalja, već i zemalja u razvoju. Uzimajući u obzir istovremeno smanjenje nataliteta, određene nacije suočavaju se s rapidnim gubitkom populacije. Prema podacima UN-a najstarija zemlja svijeta je Japan s čak $33 \%$ osoba starijih od 60 godina. Prema starosnoj strukturi slijede Njemačka i Italija s $28 \%$ te Finska s $27 \%^{1}$. Prema podacima Eurostata za 2016. godinu udio

Rezultati ovog istraživanja ukazuju na povećane potrebe osoba starije životne dobi za zdravstvenom, ali i socijalnom skrbi. Istaknuti vodeći problemi u skrbi za osobe starije životne dobi koji su obuhvaćeni ovim istraživanjem su polifarmacija, multimorbiditet, padovi i neovisnost življenja. Navedeni problemi jednako su percipirani od strane samih osoba starije životne dobi, ali i neformalnih i formalnih pružatelja usluga skrbi. Dobiveni rezultati ukazuju na potrebu provedbe daljnjih istraživanja s ciljem iznalaženja novih modela sustavne skrbi.

stanovništva starijeg od 65 godina u Republici $\mathrm{Hr}$ vatskoj iznosio je $19,2 \%$, što pokazuje nastavak trenda starenja populacije, budući da je zabilježen porast od 1,7\% u odnosu na 2006. godinu kada je bilo $17,5 \%$ stanovništva starijeg od 65 godina ${ }^{2}$. Uz zadržavanje sadašnjih trendova, očekuje se da bi se do 2030. godine broj stanovništva starijeg od 65 godina mogao udvostručiti, a do 2050. godine čak utrostručiti ${ }^{1}$.

Starenje je fiziološki proces koji karakteriziraju promjene u funkciji dobi. Definicija prema Birrenu starenje definira kao „pravilnu ili redovitu promjenu reprezentativnih organizama u reprezentativnoj okolini koje se zbivaju s protokom vremena"3. Za razliku od starenja, starost predstavlja posljednje razvojno razdoblje u životu, a ocjenjuje se prema kronološkoj dobi $(65+)$, prema socijalnim ulogama ili statusu (mirovina, umirovljenje) ili prema funkcijskom statusu (smanjenje sposobnosti) ${ }^{4}$. Istraživači razlikuju tri osnovne dimenzije: biološku, psihološku i socijalnu starost. Biološka uključuje usporavanje funkcija organizma; psihološka uključuje promjene psihičkih funkcija te prilagodbu na proces stare- nja, dok socijalna uključuje promjene u odnosu na društvo ${ }^{4,5}$. Uzroci starenja stanovništva predstavljaju kompleksan splet čimbenika, a uključuju sociodemografski razvoj, smanjenje fertiliteta te mortaliteta dojenčadi i djece, bolju edukaciju, unaprjeđenje radnog okoliša, ravnopravnosti spolova, ali i javnozdravstvena i medicinska dostignuća koja uključuju medicinske tehnologije i lijekove $^{1}$.

Zdravo starenje je proces uspješnog starenja i predstavlja koncept koji uključuje fiziološke, psihološke, društvene i osobne perspektive ${ }^{6}$. Istovremeno, vrlo je važno istaknuti da starenje stanovništva predstavlja izazov za svaki sustav $s$ obzirom na to da starije osobe imaju povećanu potrebu za raznim aspektima skrbi koje se, između ostalih, istražuju u sklopu međunarodnog europskog projekta UHCE 2.0 (od engl. Urban Health Center Europe) $)^{7}$. Grad Rijeka jedan je od pet europskih pilot-gradova u okviru navedenog projekta u kojem se provode kvalitativna i kvantitativna istraživanja te intervencije u definiranim prioritetnim područjima. Prema posljednjem popisu stanovništva iz 2011. u Rijeci živi 128.624 građana od čega je 47,4\% muškaraca i 52,6\% žena. Čak 19,7 \% populacije je starije od 65 godina, a $10 \%$ populacije starije i od 75 godina ${ }^{8}$. U Gradu Rijeci čak je $22 \%$ samačkih kućanstava u populaciji starijih od 50 godina9. S obzirom na ovakvu demografsku strukturu, Grad Rijeka predstavlja izazovnu regiju za provođenje istraživanja vezanih uz odabir i učinkovitost intervencija koje su usmjerene aktivnom i zdravom starenju, a sve s ciljem smanjenja mortaliteta i morbiditeta u starijoj životnoj dobi, koji je između ostalog pod utjecajem različitih društvenih čimbenika ${ }^{10,11}$. Recentna literatura starenje veže uz tri ključna izazova: probleme polifarmacije i adherencije na lijekove, visoku incidenciju padova i njihovu prevenciju te oslabljeno funkcioniranje odnosno iznemoglost cjelokupnog organizma ${ }^{12-16}$.

Polifarmacija je česta pojava u starijoj populaciji s obzirom na brojna kronična stanja i bolesti koje se javljaju u starijoj dobi ${ }^{17}$. Problem polifarmacije veže se uz pojavu multimorbiditeta, a provedena istraživanja u zemljama EU-a ukazuju da gotovo $24 \%$ populacije u dobi od $70-85$ godina istovremeno obolijeva od 5 i/ili više bolesti ${ }^{18}$. S druge strane postoji problem neredovitog uzimanja lije- 
kova. Postotak osoba starije životne dobi koje boluju od kroničnih bolesti, a koje ne uzimaju farmakoterapiju varira od 40 pa sve do $75 \%{ }^{17,19}$. Prema podacima Svjetske zdravstvene organizacije čak $50 \%$ pacijenata s kroničnim bolestima ne uzima lijekove ${ }^{20}$. Pravodobnim intervencijama može se povećati adherencija na lijekove i na taj način spriječiti komplikacije koje su izazvane nepravilnim i neredovitim uzimanjem lijekova, a posljedično i broj hospitalizacija, odnosno nepotrebni troškovi u zdravstvenom, ali i sustavu socijalne skrbi ${ }^{21}$.

Statistički podaci govore da se broj padova i njihove posljedice u osoba starije životne dobi povećavaju s godinama života. Prema podacima, 28 do $35 \%$ osoba starijih od 65 godina, te 32 do $42 \%$ osoba starijih od 70 godina, koje žive u zajednici, doživi pad svake godine, što uzrokuje posljedice poput smrti, komplikacija, gubitka neovisnosti i troškova ${ }^{22}$

Posljedice ozljeda koje nastaju zbog padova su vrlo česte (50 na 1000) u populaciji starijih od 65 godina te su češće u žena nego muškaraca ${ }^{22}$. Predisponirajući čimbenici za padove su mnogi (npr. vrtoglavice, neadekvatna obuća, neprilagođen stambeni prostor, slabiji vid...), a istraživanja pokazuju da se intervencijama u zajednici usmjerenim prevenciji padova oni mogu spriječiti, ${ }^{6,22,23}$. Zdravstvena edukacija putem svih kanala dobro je prihvaćena i učinkovita u prevenciji padova ${ }^{21}$. Okruženje u kojem se provode intervencije može biti različito: od domova zdravlja, mjesnih odbora (centra), sportskih dvorana, javnih površina u obliku fizičke aktivnosti, plesa ili sl. ${ }^{24,25}$

Treći veliki izazov predstavlja iznemoglost, pojam koji je često povezan sa starijom dobi, a najčešće se odnosi na fizičku slabost, kao i na psihološke i društvene dimenzije iznemoglosti koje povećavaju rizik za niz nepovoljnih zdravstvenih ishoda ${ }^{26}$. Istraživanja pokazuju da je prevalencija fizičke iznemoglosti u populaciji osoba starijih od 65 godina 9,9\%, dok je prevalencija ukupne iznemoglosti $13,6 \%{ }^{27}$. Posljedice iznemoglosti nerijetko su padovi, invaliditet, mortalitet, prijem u domove za starije i nemoćne osobe, teret obitelji te zdravstvenom i socijalnom sustavu u cjelini. Prema istraživanjima integracija skrbi može pridonijeti održanju fizičkog funkcioniranja te sprečavanju iznemoglosti u starijih osoba ${ }^{18,28}$. Intervencije u zajednici koje su pokazale učinkovitost u modelu iznemoglosti su društvena uključenost, fizička aktivnost te revizija propisanih lijekova ${ }^{20}$.

Planiranje i provođenje učinkovitih mjera intervencije uspješnije je ako se naslanja na rezultate provedenih istraživanja koji utvrđuju konkretne potrebe pripadnika starije životne dobi u određenoj populaciji, te njihova uvjerenja i stavove o specifičnosti potreba i mogućnostima za unaprjeđenje skrbi za starije osobe. Posebna skupina otvorenih pitanja povezanih sa starenjem odnosno starošću jest bioetička. Ova se pitanja donekle poklapaju s javnozdravstvenima i istraživanja su često kombinirana. Tako su, primjerice, Boddington i Featherstone proučavale problem dijagnosticiranja demencije i inkontinencije koji može ugroziti dostojanstvo starije osobe ${ }^{29}$. Izazov za moderno društvo je i dvojba koliko javnih sredstava treba izdvajati za starije, kako pri toj alokaciji biti pravedan i slično. U nekim sredinama, poput Švedske, već su suočeni s etičkom diskusijom o tome do koje mjere treba uvoditi informatičku i komunikacijsku tehnologiju, a da se ne dosegne razina dehumanizacije ${ }^{30}$. Ova, kao i mnoga druga pitanja, moraju se uzeti u obzir pri svakom javnozdravstvenom razmatranju problema starenja i starosti.

Cilj ovog rada je istraživanje stavova i percepcije o starenju, kvaliteti života u odnosu na iznemoglost, padovima i korištenju lijekova, organizaciji i kvaliteti zdravstvene i socijalne skrbi te mogućnosti unaprjeđenja zdravlja s tri različita aspekta sudionika.

\section{ISPITANICI}

U istraživanju koje je provedeno tijekom 2015. godine sudjelovalo je 40 ispitanika obaju spolova koji su bili podijeljeni u tri skupine. Skupinu A činile su osobe starije životne dobi (stariji od 75 godina, $N=12$ ), skupinu $B$ pripadnice neformalnih pružatelja usluga skrbi $(N=14)$, te skupinu $C$ pripadnici formalnih (profesionalnih) pružatelja usluga skrbi ( $N=14)$. Kriteriji za uključivanje osoba $u$ istraživanje bili su unaprijed definirani europskim projektom Urban Health Centre Europe 2.07. Zajednički uvjet za uključivanje ispitanika u grupe bili su prebivalište u gradu Rijeci (poštanski broj 51 000), odnosno obavljanje djelatnosti na području Grada Rijeke. 
Preduvjet za uključivanje formalnih pružatelja skrbi bio je minimalno pet godina radnog iskustva u pružanju skrbi za osobe starije životne dobi. Neformalni pružatelji skrbi uključivali su članove obitelji te volontere koji skrbe o osobama starije životne dobi na području Grada Rijeke, a za osobe starije životne dobi uvjet je bio da žive u vlastitu kućanstvu (da nisu u instituciji) te da nemaju dijagnosticiranu demenciju.

Skupina A osoba starijih od 75 godina obuhvaća jednak broj ispitanika obaju spolova. U braku je živjelo njih osmero, dok su četvero bili u samačkim kućanstvima. Prema podrijetlu, od 12 ispitanika samo je dvoje ispitanika zajedno s obitelji tijekom Domovinskog rata imigriralo u Rijeku, dok je većina ostalih ispitanika rođena u Gradu Rijeci ili širem gravitacijskom prstenu. Prosječna životna dob iznosila je 78,4 godine.

Skupina neformalnih pružatelja usluga skrbi (Skupina B) obuhvaća 14 ispitanika i sve su osobe ženskog spola. Među njima je bilo zastupljeno 8 volontera, te 6 članova obitelji. Prema mjestu po- drijetla 12 ih je bilo iz Rijeke i gravitacijskog prstena, a dvoje članova obitelji doselilo je tijekom Domovinskog rata u Rijeku. Prosječna životna dob iznosila je 58,2 godine.

Skupina formalnih pružatelja usluga skrbi (Skupina C) obuhvaća 14 osoba od čega 2 muškarca i 12 žena. Prema profesionalnoj pripadnosti dva ispitanika su liječnici obiteljske medicine, četiri medicinske sestre, tri patronažne sestre, četiri socijalne radnice te jedna fizioterapeutkinja. Prosječna životna dob iznosila je 44,8 godina.

\section{METODE ISTRAŽIVANJA}

Istraživanje je provedeno korištenjem metode fokus-grupa pri čemu je teoretski okvir za listu tema fokus-grupa za osobe starije životne dobi bio baziran na studiji Nardi Stevernik ${ }^{31}$. Aspekti potreba rada i ograničenih resursa vezanih uz pružanje skrbi (fizički, socijalni, organizacijski, psihološki) za formalne i neformalne pružatelje skrbi dopunjeni su prema JD-R modelu ${ }^{32}$. Ukupno je ispitano 10 tematskih područja vezanih za različite

Tablica 1. Lista tema i primjeri pitanja po ispitivanim skupinama

\section{Kategorija}

A obilježja starosne dobi

B potrebe osoba starije životne dobi

C organizacija zdravstvene i socijalne skrbi

D važnost očuvanja zdravlja

E starije životne dobi

F korištenje lijekova u starijoj dobi

G korištenje modernih tehnologija

H socijalna izolacija i diskriminacija

uloga neformalnih njegovatelja u pružanju skrbi, te izazovi u pružanju skrbi

J

unaprjeđenje zdravstvene i socijalne skrbi za osobe starije životne dobi

\section{Primjeri pitanja}

Izdvojite tri slike, odaberite jednu koja Vam je najvažnija. Molimo Vas, recite nam zašto ste odabrali upravo tu sliku?

Može li svatko od vas reći nešto o sebi - gdje živite, kako živite i s kim živite.

Što nedostaje u odnosu liječnik - pacijent i općenito u medicinskom sustavu? Opšite svoja iskustva s Domovima zdravlja.

Smatrate li da tjelovježba pomaže prevenciji padova i kvaliteti života ili su to neizbježne situacije u starijoj dobi?

Poznato je da moramo čitati, da moramo biti aktivni, da moramo zdravo jesti. Što mislite zašto se ljudi tako ne ponašaju?

Koje savjete možete dati u cilju povećanja kvalitete života osoba starije životne dobi?

Pijete li puno lijekova, jesu li Vam potrebni, koliko često ih pijete?

Koristite li se računalom i mobitelom, pomaže li Vam to? Za što ih koristite?

Predstavljaju li Vam problem mobiteli ili kompjutori?

Ima li osoba među vama za koje se netko brine ili im pomaže u svakodnevnom životu, poput obitelji, prijatelja ili susjeda?

Što mislite, trebaju li neke posebne kompetencije da bi se brinulo o starijim ukućanima? Imate li pomoć drugih osoba i koliko Vam je teško?

Što je po Vašem mišljenju struci nužno i potrebno za osobe starije životne dobi?

Na koji način bi sustav mogao funkcionirati, kako bi se mogla poboljšati trenutna situacija?

Što bi olakšalo Vašu brigu o starijima?

\section{Starije osobe}

ABCDEF GH

Neformalni pružatelji usluga zdravstvene i socijalne skrbi

$A B C D E$ IJ

Formalni pružatelji usluga zdravstvene i socijalne skrbi 
aspekte kvalitete života, zdravstvene i socijalne skrbi te mogućnosti njihova unaprjeđenja.

Ukupno je provedeno osam fokus-grupa (u svakoj skupini po dvije) sa šest do osam ispitanika, Svaka fokus-grupa trajala je 90 minuta. Po potpisivanju informirane suglasnosti, cijeli razgovor se snimao. Tonski se zapis potom prebacio u elektronički medij te analizirao metodom analize sadržaja redukcijom teksta ${ }^{33,34}$.

U sve tri skupine ispitane su percepcije i stavovi o nizu zajedničkih tema. Uvodni dio započeo je puštanjem filma u trajanju od 2,5 minute kojim se dao uvod u tematiku, a nakon toga su ispitanicima bile podijeljene fotografije (10 fotografija $u$ koverti po ispitaniku) i svaki ispitanik bio je zamoljen da odabere tri koje smatra da su važne. Fotografijama se ispitanicima olakšao razgovor o potrebama i očekivanjima.

Lista tema i primjeri pitanja po ispitivanim skupinama prikazani su u tablici 1 .

Pri obradi podataka korišten je standardni postupak kvalitativne analize koji se odnosi na kružnu analizu. Kroz četiri etape provedeno je uređenje empirijske građe, zatim su određene jedinice kodiranja, provedeno je otvoreno kodiranje te izbor i definiranje relevantnih pojmova i kategorija ${ }^{35}$.

\section{REZULTATI}

Dobiveni rezultati prikazani su u objedinjenim kategorijama za odgovarajuće tematske cjeline koje su neposredno vezane uz postavljeni cilj istraživanja (percepcija o starenju, sadašnje potrebe i očekivanja, korištenje lijekova, organizacija zdravstvene i socijalne skrbi, korištenje modernih tehnologija, unaprjeđenje zdravlja i buduće potrebe osoba starije životne dobi). Kako bi se postiglo lakše razumijevanje, dobiveni rezultati su podijeljeni u nekoliko tema, a svaka tema objedinjuje veći broj kategorija koje su detaljnije opisane.

\section{Skupina A - Osobe starije životne dobi}

Analiza odgovora u prvoj skupini ispitanika, dakle, među osobama starije životne dobi pokazala je vrlo zanimljive odgovore. Vezano uz percepciju (viziju) starosne dobi većina ispitanika je naglasila važnost obitelji, zdravih životnih stilova s najčešće spominjanom tjelovježbom, ljubavi te društvene uključenosti. Rjeđe naglašeni bili su pomoć u zajednici te duhovnost.
„... Na slici je prikazana obitelj, zatim na drugom mjestu temu zdravoga života i pod tri ovu s unucima - imam dva praunuka i četiri unuke i oni mi jako puno znače."

„... Moja unuka mi je na prvom mjestu, to je neizmjerna ljubav i jaka emocionalna veza, a onda svakako ovu sliku - zdrav život."

„... Sretna starost podrazumijeva skladan život muža i žene. To je, osobito u starosti, iznimno važno."

„... Evo, ja sam izabrala ovu s motivom gdje mladi ljudi pomažu starijima."

Vezano uz potrebe i očekivanja za potrebne usluge skrbi, većina ispitanika navodi da se nema kome obratiti ako zatrebaju pomoć. Među njima se posebno izdvajaju osobe koje su u Rijeku došle za vrijeme Domovinskog rata, te nisu ostvarile društvenu povezanost u Rijeci. Više ispitanika navodi nedostatak društvene uključenosti te marginalizaciju.

„To je zaista problem za nas koji nemamo školskih drugova, nemamo kolega sa studija, nemamo starih susjeda, nemamo poznanika s Korza - nemamo u biti prijatelja, a u godinama smo kada nestajemo jedan za drugim i smanjuje se krug onih koji mogu pomoći."

"Odlučila sam svaku večer otići u Kapucinsku crkvu, godi mi duhovnost, malo popričam s nekim $i$ to mi je sve."

„Imam prijateljice koje zdravstveno stoje lošije od mene. Ustvari, ja sam ta koja pomaže..."

Vezano uz organizaciju zdravstvene skrbi većina ispitanika smatra da je u prošlosti Dom zdravlja bio bolje organiziran, pri čemu jedan dio ispitanika za loše organiziran sustav krivi Domovinski rat.

„Prije je bilo sigurno bolje, jer nije bilo toliko siromašnih. Imali smo Dom zdravlja s ambulantama koje si mogao nazvati i svaki bi liječnik došao kada si ga pozvao. Danas samo čekate..."

„Svaki pacijent navaljuje na liječnika obiteljske medicine i traži da ga pošalje specijalistu i prijeti..."

„... da pacijenti prije vjeruju liječniku specijalistu nego liječniku obiteljske medicine."

Vezano uz pitanje o korištenju lijekova doznajemo da svi ispitanici obuhvaćeni istraživanjem koriste lijekove. Većina ispitanika koristi jedan do 
dva lijeka dnevno. Kao problem ispitanici navode izazove u plaćanju lijekova koji nisu pokriveni osnovnim i dopunskim zdravstvenim osiguranjem. Većina ispitanika se pridržava uputa za korištenje lijekova samostalno ili uz pomoć partnera. Jedan dio ispitanika si samostalno određuje doze lijekova, odnosno odbacuje određene lijekove iz uporabe. Izražavaju skepsu prema lijekovima te farmaceutskoj industriji.

„... pijem 7 vrsta lijekova."

"I ja uzimam za očni tlak, jer sam imala dvije operacije. Na to moram zaista jako paziti, kao i na higijenu očiju, jer sam sklona upalama. A lijekove ne podnosim jer sam alergična. $U$ biti ih vjerojatno samo ne volim."

"Zapravo, znam da nam se farmaceutska industrija nameće i da spušta granice kako bi zarađivala na nama i smatram da bi svi mi koji smo $u$ ovim godinama trebali zaista nastojati što manje piti lijekove."

„... multinacionalnih kompanija koje plasiraju lijekove zbog svoje dobiti, a ne zbog zdravlja ljudi."

„Uzimao sam lijekove, pa je bila takva reakcija da sam morao prestati uzimati lijekove i onda sam ozdravio."

Na pitanje vezano uz korištenje modernih tehnologija većina ispitanika je potvrdno odgovorila. Gotovo svi ispitanici posjeduju mobilne telefone. Od programskih inačica najviše se koriste Skypeom i internetom, a povremeno koriste računalo i za pisanje.

„... ja se služim internetom tako da dosta informacija pokupim surfajući..."

„... s interneta vadim razne tekstove."

"u vezi Skypea i FB-a - javili su mi se rođaci izdaleka, nisam ni znao da ih imam, a onda su mi se iz cijelog svijeta javili folkloraši."

Vezano uz mogućnosti unaprjeđenja zdravlja, utvrđeno je da veći dio ispitanika redovito provodi neki oblik tjelovježbe te prepoznaju važnost tjelovježbe u starijoj dobi.

„Fizička spremnost je važna..."

"Ne možete vi dva tjedna ne raditi tjelovježbu, treba raditi svakodnevno. Kao i što jedete svakodnevno. A valja održavati i uz fizičku i psihičku snagu."
„Hodanjem se, na primjer, kolesterol topi, tlak se smiruje, imamo bolju liniju i nismo debeli."

Neki ispitanici osjećaju strah od tjelovježbe zbog padova ili straha od padova.

„... patim od iznenadne vrtoglavice."

„... strah da ću pasti..."

„... nisam stabilna na nogama..."

Analiza odgovora pokazala je da su najčešće potrebe u skrbi koje navode osobe starije životne dobi patronažna, psihološka i psihijatrijska skrb.

„... psihijatri mogli pomoći..."

„... psihološku pomoć bismo itekako trebali..."

„... fizičkoj iznemoglosti onda treba nam patronaža..."

"Sigurno bi psihijatri i psiholozi kod nas imali posla..."

„...odlučim svoje zdravlje dalje rješavati privatno."

Neki ispitanici naglašavaju problem društvene izolacije i nedovoljno aktivnosti u organizaciji jedinice lokalne samouprave.

„... obliku druženja gdje bi se skupili oni koji ne mogu hodati..."

„... dobro da ponekad imamo društvo..."

$\mathrm{U}$ analizi odgovora vezanih uz probleme socijalne izolacije i diskriminacije, uočava se da većina ispitanika naglašava da jedan dio problema socijalne izolacije, ali i lošijeg zdravlja, leži u nedostatku financijskih sredstava. Također spominju i diskriminaciju, ali i marginalizaciju osoba starije životne dobi u društvu.

„... jedan aspekt druženja, koji mi umirovljenici stidljivo spominjemo, su financije."

„... kupovati zdravu prehranu koja je skuplja od ostale prehrane..."

„... razmišljam o svakoj lipi."

„... u dobi kada Vas nitko više ne primjećuje..."

„... ti si umirovljenik, imaš vremena, pa čekaj!"

"Nema više susjeda, ni prijatelja."

\section{Skupina B - Neformalni pružatelji usluga skrbi}

Nakon provedene analize odgovora pripadnika Skupine B mogu se izdvojiti sljedeći stavovi, imajući u vidu da su osobe u ovoj skupini prvenstveno članovi obitelji starijih osoba koje zahtijevaju dodatnu skrb, kao i volonteri koji nisu službeno educirani za zdravstvenu njegu. 
Neformalni njegovatelji percipiraju osobe starije životne dobi kao populaciju koja je opterećena bolestima i ovisna o drugima. Smatraju da je socijalna uključenost iznimno važna, kao i očuvanje fizičkog zdravlja.

„... potpuno je ovisna o meni i slušala je savijete." „... ima probleme s tlakom i srcem te vrtoglavicama i zaboravljivošću, tj. demencijom."

„... trebaju me za razgovor i druženje..."

„Društvo njima treba..."

„... ne prihvaćaju svoju starost. Ne prihvaćaju da ne mogu, ne prihvaćaju skrb i ponekad se i ljute." "Budućnost je u rukama starijih..."

„... ne vidim sebe u pozitivnom položaju, već negativnom."

„... briga za mamu počinje u 5 ujutro."

„... potpuno je usmjerena na mene i moju obitelj.“

Pri opisivanju stanja i potreba osoba starije životne dobi neformalni pružatelji usluga skrbi, pored ranije navedenih stavova, ukazuju te naglašavaju potrebu za profesionalnom njegom. Jasno se ističe $i$ problem samoizlaganja rizicima, ali i loše financijsko stanje koje rezultira smanjenjem kvalitete zdravstvene skrbi, ali i socijalnom izolacijom.

„... u jednom periodu je potreba za patronažnom sestrom, u jednom periodu je potreba za psihijatrijom, u drugom trenutku je opet potreba za njegom..."

„... ne osjećam se kompetentno da bih ja njima mogla pomoći..."

„... i strah da iz svog neznanja nešto ne zeznem."

Analiza odgovora vezanih uz organizaciju zdravstvene i socijalne skrbi ukazuje da ispitanici postojeću skrb vide kao nedostatnu, nedostupnu i skupu. Smatraju da je sustav zdravstvene skrbi odvojen od sustava socijalne skrbi i u potpunosti nepovezan. U ostvarenju odgovarajuće zdravstvene skrbi navode probleme nedostatnih financija za adekvatnu skrb.

„Sustav je kompletno neuređen. Za sve moraš imati novaca. Ako želiš ići na preglede, moraš imati vezu."

„... idu na neke preglede u bolnice još dođe ujutro po njih prijevoz, ali za nazad... do navečer čekaju."

„... imamo nedovoljno ljudi, imamo premalo novaca da bi uzeli ljude..."
„... kada idete na liječnički pregled - žena mora imati donjeg rublja, to je prva stvar, zatim čarape, a gdje je kozmetika za higijenu, četkica za zube..."

„Nove mirovine su male, 2000, 1800 kn, što se s tim može? Treba s 500 kuna živjeti cijeli mjesec. Dok platite sve račune, ništa ne ostane. Morate računati da 500 kuna sigurno ode za režije - struja, telefon, stanarina. A gdje su lijekovi?"

Većina ispitanika prepoznaje padove kao vrlo čest uzrok smanjene kvalitete života i socijalne izolacije. Neki ispitanici navode (članovi obitelji) da osobe starije životne dobi ne žele ići u domove za starije i nemoćne.

„... već puno, puno godina prije toga rekla je da nema šanse da je damo u dom."

Prilikom opisivanja vlastite uloge neformalnih njegovatelja u pružanju skrbi, te izazova u pružanju skrbi, mogu se uočiti razlike između pripadnika koji su iz podskupine članova obitelji u odnosu na podskupinu volontera. Naime, kod pripadnika podskupine članova obitelji prisutna je veća količina nezadovoljstva, stresa i strepnje u skrbi za osobe starije životne dobi, što je i očekivano s obzirom na obiteljsku i snažnu emocionalnu povezanost. Ispitanici ističu vlastito samožrtvovanje i odricanje naglašavajući da obavljaju sve vezano uz skrb za svojeg člana obitelji, što se odnosi na poslove u spektru od davanja lijekova, nabavke namirnica, kuhanja, do čišćenja i osobne higijene. Istaknuti su i osobni problemi neformalnih njegovatelja - članova obitelji koji uključuju narušenu kvalitetu života, ali i osjećaj bespomoćnosti zbog nedostatka potrebne vještine za skrb, te svoju ulogu usmjeravaju prema brizi za osnovne životne potrebe, druženju i pažnji te pružanju zdravstvene skrbi.

"Nisam zdravstveni profesionalac i proživljavam to izrazito stresno."

„Ne znam što ću zateći kada dođem s posla. Odlazak kući je za mene izuzetan stres."

„... uopće se ne osjećam kompetentno da bih ja njima mogla pomoći."

„Ja vidim da sam umorna."

Za razliku od članova obitelji, volonteri smatraju da im rad s osobama starije dobi pomaže u osob- 
nom razvoju, naglašavajući da ih ispunjava život kroz pomoć drugima. Volonteri sudjeluju u radu klubova umirovljenika odnosno molitvene zajednice, a u svojim udrugama organiziraju proslave rođendana, praznika, organiziraju izlete za osobe starije životne dobi. Volonteri ističu da su osobe starije životne dobi s kojima rade najčešće usamljene.

„... mi ih posjećujemo, čestitke im šaljemo..."

"Mi smo za zabavu!"

„... mi svaki praznik slavimo večericom..."

Neformalni pružatelji usluge skrbi naglašavaju potrebu za zdravstvenim profesionalcima koji uključuju različite profesije ovisno o stanju osobe o kojoj skrbe. Najčešće se navodi potreba za postojanjem patronažne skrbi, psihijatrijske skrbi i psihološke pomoći. Svi ispitanici navode da je u starosti važna socijalna inkluzija, pri čemu naglašavaju važnost vršnjačkog podupiranja.

„... važno je, recimo, kad legne u krevet da postoji neka patronažna sestra, neka osoba koja je vična pranju, pomicanju, presvlačenju..."

„... u jednom periodu je potreba za patronažnom sestrom, u jednom periodu je potreba za psihijatrijom, u drugom trenutku je opet potreba za njegom..."

„... barem jednom godišnje trebalo bi otići na terapije u lječilište..."

„... ljudi žele ili sestru ili njegovateljicu, da ih operu."

"Njima trebaju ljudi sa sličnim bolestima... imaju o čemu pričati i onda nađu i druge teme..."

„... trebalo bi se organizirati i onda bismo bili zdraviji..."

Na pitanje o unaprjeđenju skrbi neformalni pružatelji skrbi iskazuju potrebu za pomoći zdravstvenih profesionalaca te prilagođenih oblika izvaninstitucijske zdravstvene, ali i socijalne skrbi. Iskustva sa sustavom zdravstvene i socijalne skrbi karakteriziraju učestali posjeti zdravstvu, veće povjerenje u privatno zdravstvo, uočavanje i ukazivanje na probleme u javnom zdravstvu te nedostatak zdravstvene pismenosti (slaba informiranost). Kroz razgovor je uočena i potreba za reevaluacijom pozicije liječnika obiteljske medicine.
"Sustav je kompletno neuređen. Za sve moraš imati novaca. Ako želiš ići na preglede, moraš imati vezu."

„... kad idu na neke preglede u bolnice još dođe ujutro po njih prijevoz ali za nazad... do navečer čekaju."

„... drugačije to organizirati. Kako ja to ne znam jer nisam medicinske struke i nisam inače organizator to jest ne poznajem dobro sustav koji bi trebalo organizirati."

"Imamo neuređen sustav, imamo nedovoljno ljudi, imamo premalo novaca da bi uzeli ljude, da bi ležerno išli na posao i ležerno proveli život..."

„Uglavnom se informiraju preko televizije; mi smo imali predavanja o inkontinenciji..."

„Lijekove prepisuju specijalisti, a opća praksa mora slijediti što oni napišu."

\section{Skupina C - Formalni pružatelji usluga zdravstvene i socijalne skrbi}

Na temelju iskustva u radu s osobama starije životne dobi formalni pružatelji usluga zdravstvene i socijalne skrbi navode najznačajnije probleme, poput nedostatka skrbi zajednice, izostanak i važnost primarne prevencije, nužnost očuvanja neovisnosti, važnost komunikacije, važnost emocionalne podrške te nužnost destigmatizacija.

„... barem im pružiti emocionalnu podršku i dati tim ljudima osjećaj da su nekome važni..."

„... dati im informaciju... najvažnija je komunikacija sa starijom osobom."

„... osobnu podršku i tu organiziranu podršku."

„... ne stigmatiziranje starijih osoba i zatvaranje unutar svojih domova."

"Razvijati primarne prevencije... neovisnost apsolutno i sposobnost..."

Od specifičnih potreba osoba starije životne dobi formalni pružatelji usluga zdravstvene i socijalne skrbi najčešće navode problem nebrige djece za roditelje (osobe starije životne dobi), te njihovo očekivanje od zdravstvenog i socijalnog sustava da sustav, a ne oni, preuzmu brigu o roditeljima. Također se navodi uočljivo nepoznavanje zakonskih okvira prema kojima su djeca dužna skrbiti za svoje roditelje. Među izazovima o brizi za starije životne dobi navode reakcije kojima starije osobe odbijaju djecu. 
„... ima obitelji koje i odbacuju tu osobu i zlouporabe radi koristoljublja, materijalnih interesa... prije svega stan i mirovina i onda odbacivanje..." „... vi se morate pobrinuti za svoje roditelje, to je vaša zakonska obaveza."

„... djeca traže od zdravstva da se zdravstvo pobrine za njihove roditelje..."

Formalni pružatelji usluga zdravstvene i socijalne skrbi uočavaju problem velikog broja propisanih lijekova koje bi trebale koristiti osobe starije životne dobi, ali ukazuju i na problem odbijanja uzimanja propisane terapije, što dovodi do gomilanja lijekova i velikih troškova u zdravstvu. Ispitanici iz ove skupine koji su profesionalno po zvanju patronažne sestre posebno ukazuju na problem gomilanje lijekova u domovima korisnika.

„Važno je da imaju puno tableta jer onda su oni face. To je kao djeca kad skupljaju sličice..."

„... kolekciju lijekova za par godina unaprijed..."

Posebno se ističe otpor prema mijenjanju životnih navika osoba starije životne dobi, koje su usmjerene na tjelovježbu, te nužnost prilagodbe kućanstva (ugradnja držača) ili kupnja adekvatne obuće kako bi se izbjegao rizik od padova u vlastitom kućanstvu. Nadalje, većina ispitanika navodi skromnu financijsku situaciju koja onemogućava osobama starije životne dobi kvalitetniji život, ali i skrb.

„... svaki prijevoz hitne isto se plaća."

„... priuštiti fizioterapeuta privatno."

„... mogli bi si s vremena na vrijeme priuštiti neka putovanja, to bi ih dalje motiviralo..."

Za uspješnu suradnju u procesu skrbi za osobe starije životne dobi većina ispitanika iz ove skupine naglašava važnost dobre suradnje patronažne, socijalne skrbi te liječnika obiteljske medicine.

„... sva ona suradnja i osobna i što pratim kolege sasvim ok."

„... funkcionira razmjena podataka."

„... magični trokut - socijalna služba, patronaža $i$ liječnik."

Kao najveći nedostatak u skrbi za osobe starije životne dobi ispitanici iz ove skupine navode nedostatak vremena te probleme koji proizlaze iz propisanih normativa u zdravstvenoj skrbi.
„Dođeš kod nepokretne osobe, a ona ima dva sata zdravstvene njege..."

„... nije adekvatna briga za nepokretnog pacijenta."

Kvaliteta skrbi sukladno mišljenjima ispitanika može se unaprijediti povećanjem broja zaposlenih u socijalnoj i zdravstvenoj skrbi. Također se spominje i formiranje „nove službe“ koja neće biti vezana uz Dom zdravlja ili Centar za socijalnu skrb već skrbiti o osobama starije životne dobi. Ispitanici također navode potrebu decentralizacije sustava socijalne skrbi pri čemu bi se veća odgovornost prepustila jedinicama lokalne uprave i samouprave koje su upoznate s problematikom građana. Pojednostavljivanje zakona, prema nekima, nužno je, kao i smanjenje broja pravilnika koji sustavno prolaze izmjene i dopune.

„... decentralizacija sustava općenito. O tome ovisi i ova skrb o starijim osobama. Spustiti na nivo gradova, općina i županija. Decentralizirati i da se time bave oni ljudi koji neposredno rade i upoznati su s problemima i karakteristikama sredina..."

„... se stalno dovodi novi zakon i novi pravilnici $i$ stalno šuma propisa i normativnih zakona."

Organizaciju zdravstvenog sustava profesionalci karakteriziraju kao opterećenu papirologijom, bez vremena za komunikaciju. Nepovjerenje u liječnike obiteljske medicine izazov je s kojim se suočavaju zdravstveni profesionalci u skrbi.

„... Dođe s otpusnim pismom... dok se to sve upiše, protokolira, to prođe minimalno jedno dvadesetak minuta i to baš ako si brz..."

„... sve više $i$ više se žale $i$ u bolnici $i$ kod nas da nije doktora ni vidio, da doktor ne gleda u njega nego u ekran i da nema komunikacije...", „... sakupimo tri nalaza specijalista i sad želimo tu nešto eventualno reducirati, što $i$ jest opravdano, ali puno puta neće oni ni vjerovati, jer, uvijek će reći - specijalist je to propisao..."

\section{RASPRAVA}

Provedeno istraživanje ukazuje na mnoga otvorena pitanja i multidimenzionalnost percepcije starosti osoba starije životne dobi kao i osoba u neposrednom kontaktu s istima. Osobe starije ži- 
votne dobi definirale su prioritete u životu koji uključuju obiteljsku povezanost, prevenciju bolesti i društvenu uključenost. Dobiveni rezultati $u$ suglasju su s istraživanjem provedenim u Velikoj Britaniji koje je obuhvaćalo populaciju osoba starijih od 65 godina ${ }^{36}$. lako se percepcija starosti uglavnom poklapa kod pripadnika različitih skupina ispitanika, uočena je razlika između grupe neformalnih i formalnih pružatelja usluga skrbi, pri čemu se ističe važnost neovisnosti starijih osoba u skupini formalnih njegovatelja, dok skupina neformalnih pružatelja skrbi navodi izrazitu važnost organizirane skrbi i veće odgovornosti zajednice za skrb o osobama starije životne dobi.

Provedena analiza istaknutih potreba u skrbi za osobe starije životne dobi ukazuje da se kao najvažniji problemi, a uz to vezane potrebe, ističu polifarmacija, multimorbiditet i padovi, kao i strah od padova. Sve tri ispitivane skupine suglasne su kako je od izuzetne važnosti očuvanje neovisnosti osoba starije životne dobi kroz intervencije promicanja zdravlja i prevencije bolesti ${ }^{12,16,20,26,33,34}$. Dobiveni rezultati ukazuju na značajne razlike u stavovima različitih skupina o potrebama osoba starije životne dobi za skrbi. Ispitanici iz Skupine A posebice naglašavaju nedovoljnu društvenu uključenost i marginalizaciju, kao i zdravstveni profesionalci (Skupina C) ${ }^{36}$. Nasuprot tome ispitanici iz skupine neformalnih pružatelja skrbi ističu potrebu za višom razinom dostupnosti profesionalne skrbi te nedovoljnu razinu odgovornosti starijih $u$ odnosu na vlastito zdravlje. Literaturni podaci upućuju na povezanost starije životne dobi $s$ nekim negativnim zdravstvenim ponašanjima, poput neodržavanja osobne i okolišne higijene, fizičke i psihičke neaktivnosti, neprihvaćanja radne terapije, naglašavajući važnost problema nepridržavanja uputa liječnika i nekontroliranog uzimanja lijekova, što je u suglasju s našim istraživanjem ${ }^{39}$.

Stavovi osoba starije životne dobi o organizaciji zdravstvene i socijalne skrbi ukazuju na lošiju razinu postojećih sustava u odnosu na situaciju prije Domovinskog rata, što iznose i neformalni pružatelji skrbi koji uz to navode i problem nepovezanosti sustava zdravstvene i sustava socijalne skrbi. S druge strane, zdravstveni profesionalci ističu problem nedostatka djelatnika u zdravstvu i socijalnoj skrbi, nedostatak vremena za cjelovitu skrb te kompleksnu administraciju i legislativu koja je podložna učestalim promjenama. Prema njihovim stavovima bilo bi poželjno skrb o starijim osobama organizirati unutar nove specijalizirane službe koja bi u potpunosti bila posvećena zadovoljenu i zdravstvenih i socijalnih potreba starije populacije. Na potrebu reorganizacije i integracije sustava zdravstvene i socijalne skrbi za starije osobe ukazuju i rezultati nedavno objavljenih istraživanja s posebnim naglaskom na prioritetna područja multimorbiditeta, polifarmacije, prevencije padova i iznemoglosti ${ }^{6,7}$. Ovim istraživanjem u svim ispitivanim skupinama naglašava se da je zdravstvena skrb skupa, pri čemu loše materijalno stanje utječe ne samo na kvalitetu zdravstvene skrbi već i na cjelokupnu kvalitetu života. Neformalni njegovatelji smatraju da je potrebno organizirati oblike izvaninstitucijske skrbi i povećati informiranost osoba starije životne dobi, pri čemu bi teret skrbi o osobama starije životne dobi za neformalne njegovatelje bio značajno manji.

Porast prevalencije multimorbiditeta u starijoj populaciji povezan je s povećanjem broja posjeta liječniku obiteljske medicine i kompleksnosti skrbi koju pruža takvim pacijentima. Radi se o povezanim problemima, budući da je posljedica multimorbiditeta polifarmacija koja je opisana upravo kao karakteristika osoba starije životne dobi u svim fokus-grupama. Stavovi ispitanika osoba starije životne dobi koji se odnose na zdravstveni sustav ukazuju na nedovoljnu koordiniranost, nisku razinu povjerenja prema liječnicima obiteljske medicine te istaknutu skepsu prema farmaceutskoj industriji, što djelomično rezultira nižom adherencijom na lijekove. Sukladno navedenom ispitanice, patronažne sestre, $s$ pravom prepoznaju postojanje velike količine neiskorištenih lijekova u domaćinstvima korisnika. Na problem adherencije ukazuju brojna istraživanja u svijetu, a prema nekima od njih adherencija na lijekove kroničnih pacijenata iznosi tek oko $50 \%{ }^{14,39}$. Slaba adherencija glavni je razlog neuspješnoga kliničkog ishoda, ali i potencijalnog trošenja sredstava za liječenje komplikacija bolesti uslijed neuspješnog liječenja. Nedavno provedeno istraživanje u RH pokazalo je da je glavni razlog neadherencije prema dugotrajnoj medikaciji zaboravljivost (60\%), izbivanje iz kuće u vrijeme 
uzimanja lijeka $(45,4 \%)$, pomanjkanje zaliha lijeka (44,4\%), neodgovarajući termin uzimanja lijeka $(40,9 \%)$ odnosno uzimanje više različitih lijekova (39,5\%). Nadalje, navodi se razlog trenutnog nedostatka propisanog lijeka u ljekarni bez odgovarajuće zamjene (35,9\%), trenutni izostanak zdravstvenih smetnji (35,9\%) te želja za izbjegavanjem neželjenih učinaka lijeka $(29,6 \%)^{40}$. Pored navedenog, istraživanja ukazuju na potrebu za kliničkom revizijom i menadžmentom propisane medikacije s ciljem povećanja adherencije i ušteda u zdravstvu. Dobra komunikacija na relaciji liječnik-pacijent uvelike pomaže pri uspostavi ustrajnosti, što pokazuje i ovo istraživanje. Naime, osim povećanja adherencije na lijekove, prema stavovima ispitanika iz skupine A i B, bilo bi potrebno učvrstiti poziciju liječnika obiteljske medicine u zdravstvenom sustavu u odnosu na autoritet koji trenutno imaju liječnici specijalisti. Pri tom bi se, osim boljih ishoda liječenja, postigli i dodatni pozitivni učinci na zdravstveni sustav (rasterećenje pojedinih dionika) kao i na zdravstveni proračun: smanjenje troškova za dodatne intervencije ${ }^{41}$.

lako postoji stereotipno mišljenje kako se osobe starije životne dobi ograničeno koriste modernom tehnologijom, ispitanici iz skupine A pokazali su visok stupanj zainteresiranosti i motiviranosti za učenje njihova korištenja. Rezultati ranije provedenog istraživanja u sklopu projekta UHCE pokazali su kako ima smisla razvijati programe koji će osobe starije životne dobi podsjećati i stimulirati na korištenje propisane terapije te na taj način povećati adherenciju na lijekove, kao i društveno umrežavanje koje korisnicima pomažu u održavanju kontakata s obitelji i prijateljima te pristupa informacijama o sadržajima koji ih interesiraju ${ }^{7}$. Na taj se način pored pozitivnih učinaka na društveni život otvaraju mogućnosti i za zdravstveno opismenjavanje, unaprjeđenje društvene potpore i terapeutskog procesa i njegovog ishoda. Prema rezultatima ranijih istraživanja sveobuhvatnim i sustavnim komuniciranjem kroz više medija može se postići sprječavanje komplikacija kroničnih bolesti i postići značajne uštede u zdravstvenom sustavu ${ }^{42}$.

Značaj neformalne skrbi za osobe starije životne dobi iznimno je velik, s obzirom na to da takav vid skrbi smanjuje troškove društvene zajednice te rasterećuje formalne pružatelje skrbi. No, usprkos nedvojbenim koristima za širu društvenu zajednicu, ne smije se zanemariti postojanje objektivnih problema s kojima se susreću neformalni pružatelji usluga, a koje je potvrdilo i ovo istraživanje. Spomenuti problemi odnose se na smanjenu kvalitetu života, dodatnu opterećenost (osobito u onih ispitanika koji su članovi obitelji starijih osoba, a koji imaju i svoje redovite radne obveze) te neizvjesnost i stres s kojima se neformalni pružatelji skrbi suočavaju ${ }^{44}$. Ovo je istraživanje pokazalo kako su nedostatak znanja i vještina za rješavanje zdravstvene problematike u osoba starije životne dobi upravo podloga koja osobito opterećuje neformalne pružatelje skrbi s posljedičnom neizvjesnošću, strahom i stresom. Zbog toga je važnost podrške zajednice i prepoznavanje uloge neformalnih njegovatelja svakako imperativ za društvo koje stari. Demerouti i Bakker (2011) u provedenom istraživanju potreba rada i resursa kod zdravstvenih struka navode važnost balansiranja između zahtjeva/potreba posla (fizički, socijalni, organizacijski, psihološki) i resursa koji stoje na raspolaganju, a koji će smanjiti pritisak na potrebu angažmana zdravstvenog osoblja i omogućiti nesmetan rad, osobni rast i razvoj $^{32}$.

U provedenom istraživanju formalni pružatelji skrbi jasno naglašavaju izazove u području odgovornosti članova obitelji za osobe starije životne dobi koja, iako zakonski regulirana, u praksi ponekad nije zaživjela. Pored toga formalni pružatelji usluga naglašavaju i neodgovornost osoba starije životne dobi koja se očituje odbijanjem promjena životnih stilova u svrhu što duljeg očuvanja neovisnosti, što ističu i neformalni pružatelji usluga skrbi.

Ranija istraživanja provedena u domaćinstvima osoba starije životne dobi pokazala su da čak $80 \%$ ispitanika u svom kućanstvu ima barem jedno mjesto rizično za padove, a u gotovo $40 \%$ prisutno ih je čak $5^{43}$. Pored zdravstvenih posljedica za same starije osobe, dodatna skrb koju im u slučaju padova trebaju pružati i neformalni i formalni pružatelji još više naglašava potrebu prevencije zdravstvenih rizičnih ponašanja u osoba starije životne dobi.

Padovi u starijoj dobi česti su uzrok disabiliteta. Oko trećina osoba starije životne dobi doživi pad 
u vlastitom domu svake godine, čak $10 \%$ padova završi frakturom i potrebom za zdravstvenom skr$b^{16}{ }^{16}$. Padovi često rezultiraju i komplikacijama koje uključuju fizičku neovisnost, društvenu izolaciju i posljedičnu iznemoglost ${ }^{12}$. Rezultati ovog istraživanja također ukazuju na važnost mijenjanja postojećih, te usvajanja zdravih stilova života u starijih osoba, što je u skladu s rezultatima prethodnih istraživanja ${ }^{44,45}$. Pored javnozdravstvenog aspekta, ovo je istraživanje ukazalo i na niz bioetičkih pitanja koja se spominju u relevantnoj literaturi, poput straha od tehnologije, manjka sredstava i pružatelja skrbi, diskriminacije (,stereotipizacija“) kako pri pružanju usluga tako i u širem društvenom kontekstu i sl. ${ }^{30,46}$

Rješenje ovih problema, na koje očito ni naša sredina nije imuna, krije se u kontinuiranom kvalitetnom gerontološkom obrazovanju zdravstvenog kadra i opće populacije.

\section{ZAKLJUČAK}

Prema popisu stanovništva iz 2011. godine Hrvatska je s udjelom starijeg stanovništva od preko $17 \%$ iznad prosjeka zemalja Europske unije. Navedeni demografski pokazatelji govore da je $\mathrm{Hr}$ vatska zakoračila u "demografsku starost". Rezultati ovog istraživanja ukazuju na povećane potrebe osoba starije životne dobi za zdravstvenom, ali i socijalnom skrbi. Istaknuti vodeći problemi u skrbi za osobe starije životne dobi koji su obuhvaćeni ovim istraživanjem su polifarmacija, multimorbiditet, padovi i neovisnost življenja. Navedeni problemi jednako su percipirani od strane samih osoba starije životne dobi, ali i neformalnih i formalnih pružatelja usluga skrbi. Dobiveni rezultati ukazuju na potrebu provedbe daljnjih istraživanja s ciljem iznalaženja novih modela sustavne skrbi. Održivi modeli cjelovite sustavne skrbi za osobe starije životne dobi zasigurno zahtijevaju suradnju različitih sektora (zdravstveni sektor, sektor socijalne skrbi, nevladine organizacije i sektor znanosti) na svim razinama (lokalna, regionalna, nacionalna, nadnacionalna), što je temeljni preduvjet uspješne implementacije intervencija u zajednici. Ovim je istraživanjem dodatno naglašeno i značenje intervencija u smislu promicanja zdravlja, unaprjeđenja zdravstvene pismenosti i prevencije bolesti u svim dobnim skupinama s ciljem kvalitetnog, aktivnog i zdravog starenja.

Izjava o sukobu interesa: Autori izjavljuju da ne postoji sukob interesa.

\section{LITERATURA}

1. World Population Ageing: 1950-2050. [Internet]. New York: Department of Economic and Social Affairs United Nations, Inc. c2002 [cited 2018 Apr 17]. Available from: http://www.un.org/esa/population/publications/worldageing19502050/.

2. Population structure and ageing [Internet]. Luxembourg: European Commission. Inc. 2012 [cited 2018 Apr 17]. Available from: http://ec.europa.eu/eurostat/statisticsexplained/index.php/Population_structure_and_ ageing\#Main_statistical_findings/.

3. Birren JE, Schroots JJF. History, concepts, and theory in the psychology of aging. In: J. E. Birren \& K. W. Schaie (Eds.), Handbook of the psychology of aging ( $4^{\text {th }}$ Edition). San Diego: Academic Press.1996;23-3.

4. Štambuk A, Despot Lučanin J. Iskustvo starenja. Doprinos teoriji starenja [Internet]. Jastrebarsko: Naklada Slap; 2003 [cited 2018 May 14]. 238 p. Available from: https://www.bib.irb.hr/184821/.

5. Duraković Z. Gerijatrija - medicina starije dobi. $2^{\text {nd }}$ Edition. Zagreb: C.T. Poslovne informacije d. o. o., 2007;588-8.

6. Hansen-Kyle L. A Concept Analysis of Healthy Aging. Nurs Forum 2005;40:45-7.

7. Franse $C B$, Voorham AJJ, van Staveren R, Koppelaar E, Martijn R, Valía-Cotanda E, et al. Evaluation design of Urban Health Centres Europe (UHCE): preventive integrated health and social care for community-dwelling older persons in five European cities. BMC Geriatr 2017; 17:209.

8. Popis stanovništva, kućanstava i stanova 2011. Stanovništvo prema spolu i starosti [Internet]. Zagreb; Inc. 2013 [cited 2018 Apr 9]. Available from: https://www. dzs.hr/Hrv_Eng/publication/2012/SI-1468.pdf/.

9. Dankić K, Domiter M. Rijeka u kojoj i stariji plivaju uzvodno - Strategija zdravog starenja u Rijeci 2009 - 2013. Rijeka: Grad Rijeka, 2009;12.

10. Cohen S. Social relationships and health. Am Psychol 2004;59:676-84

11. Holt-Lunstad J, Smith TB, Layton JB. Social Relationships and Mortality Risk: A Meta-analytic Review. PLoS Med 2010;7:e1000316.

12. Scheffer AC, Schuurmans MJ, van Dijk N, van der Hooft T, de Rooij SE. Fear of falling: measurement strategy, prevalence, risk factors and consequences among older persons. Age Ageing 2008;37:19-24.

13. Spinewine A, Schmader KE, Barber N, Hughes C, Lapane $\mathrm{KL}$, Swine $\mathrm{C}$ et al. Appropriate prescribing in elderly people: how well can it be measured and optimised? Lancet 2007;370:173-84.

14. Brown MT, Bussell JK. Medication adherence: WHO cares? Mayo Clin Proc 2011;86:304-14.

15. Chin A Paw MJ, Dekker JM, Feskens EJ, Schouten EG, Kromhout D. How to select a frail elderly population? A comparison of three working definitions. J Clin Epidemiol 1999;52:1015-21. 
16. Gillespie LD, Robertson MC, Gillespie WJ, Sherrington C, Gates S, Clemson LM et al. Interventions for preventing falls in older people living in the community. Cochrane Database Syst Rev 2012;12:CD007146.

17. Adherence To Long-Term Therapies: Evidence for Action. [Internet]. Geneva: World Health Organization(WHO); 2015;Cap XIII 107-114. [cited 2018 May 8]. Available from: http://apps.who.int/iris/bitstream/handle/10665/42682/9241545992.pdf;jsessionid=E855ECA4A EB32FF46819C493AA3AEF52?sequence $=1 /$.

18. Spoorenberg SL, Uittenbroek RJ, Middel B, Kremer BP, Reijneveld SA, Wynia K. Embrace, a model for integrated elderly care: study protocol of a randomized controlled trial on the effectiveness regarding patient outcomes, service use, costs, and quality of care. BMC Geriatr 2013;13:62.

19. Doggrell SA. Adherence to medicines in the older-aged with chronic conditions: Does intervention by an allied health professional help? Drugs Aging 2010;27:239-54.

20. Daniels R, van Rossum E, Metzelthin S, Sipers W, Habets $\mathrm{H}$, Hobma $\mathrm{S}$ et al. A disability prevention programme for community-dwelling frail older persons. Clin Rehabil 2011;25:963-74.

21. Hill AM, Etherton-Beer C, Haines TP. Tailored Education for Older Patients to Facilitate Engagement in Falls Prevention Strategies after Hospital Discharge-A Pilot Randomized Controlled Trial. PLoS One 2013;8:e63450.

22. Yoshida S. A Global Report on Falls Prevention Epidemiology of Falls. WHO Rep. [Internet] Inc. 2007 [cited 2018 May 7]. Available from: http://www.who.int/ageing/projects/1.Epidemiology\%20of\%20falls\%20in\%20older\%20 age.pdf/.

23. Gillespie LD, Gillespie WJ, Robertson MC, Lamb SE, Cumming RG, Rowe $\mathrm{BH}$. Interventions for preventing falls in elderly people. Cochrane Database Syst Rev. 2003; CD000340.

24. Freiberger E, Blank WA, Salb J, Geilhof B, Hentschke C, Landendoerfer $\mathrm{P}$, et al. Effects of a complex intervention on fall risk in the general practitioner setting: a cluster randomized controlled trial. Clin Interv Aging 2013;8:1079-88.

25. Merom D, Cumming R, Mathieu E, Anstey KJ, Rissel C, Simpson JM et al. Can social dancing prevent falls in older adults? a protocol of the Dance, Aging, Cognition, Economics (DAnCE) fall prevention randomised controIled trial. BMC Public Health 2013;13:477.

26. Coelho T, Paúl C, Gobbens RJJ, Fernandes L. Determinants of frailty: the added value of assessing medication. Front Aging Neurosci 2015;7:56.

27. Collard RM, Boter H, Schoevers RA, Oude Voshaar RC. Prevalence of frailty in community-dwelling older persons: A systematic review. J Am Geriatr Soc 2012;60:1487-92.

28. Markle-Reid M, Browne G, Gafni A. Nurse-led health promotion interventions improve quality of life in frail older home care clients: lessons learned from three randomized trials in Ontario, Canada. J Eval Clin Pract 2013;19:118-31.
29. Boddington $P$, Featherstone $K$. The canary in the coal mine: Continence care for people with dementia in acute hospital wards as a crisis of dehumanization. Bioethics 2018;32:251-60.

30. Sävenstedt S, Sandman PO, Zingmark K. The duality in using information and communication technology in elder care. J Adv Nurs 2006;56:17-25.

31. Steverink N. Successful development and ageing: Theory and intervention. The Oxford handbook of clinical geropsychology. Oxford University Press, 2014;84-103.

32. Demerouti E, Bakker A.B. The job demands-resources model: Challenges for future research. $s$ Journal of Industrial Psychology 2011;37:1-9.

33. Bekheit S, Murtagh JG, Morton P, Fletcher E. New concepts of heart block. Ir J Med Sci 1973;142:329-41.

34. Patton MQ. Qualitative evaluation and research methods. $4^{\text {th }}$ Edition. Sage Publications, 1990;69-86.

35. Mesec B, Lamovec T. Uvod v kvalitativno raziskovanje $v$ socialnem delu. Visoka šola za socialno delo, 1998.

36. Gabriel Z, Bowling A. Quality of life from the perspectives of older people. Ageing Soc 2004;24:675-91.

37. Maher RL, Hanlon J, Hajjar ER, Hajjar ER. Clinical consequences of polypharmacy in elderly. Expert Opin Drug Saf 2014;13:57-65.

38. Stenhagen $M$, Ekström H, Nordell E, Elmståhl S. Falls in the general elderly population: a 3- and 6-year prospective study of risk factors using data from the longitudinal population study "Good ageing in Skane". BMC Geriatr 2013;13:81.

39. The pursuit of responsible use of medicines: sharing and learning from country experiences. No. WHO/EMP/ MAR/2012.3. [Internet]. Geneva: World Health Organization. Inc.2012. [cited 2018 May 8] Available from: https://www.who.int/medicines/publications/responsible_use/en/.

40. Čulig J. Adherencija pacijenata prema propisanoj medikaciji. J Appl Heal Sci 2018;4:7-14.

41. Salzman C, Kupfer DJ, Frank E. Medication compliance in the elderly. J Clin Psychiatry 1995;56:18-23.

42. Fang ML, Canham SL, Battersby L, Sixsmith J, Wada M, Sixsmith A. Exploring Privilege in the Digital Divide: Implications for Theory, Policy, and Practice. Gerontologist 2019;59:e1-15.

43. Carter SE, Campbell EM, Sanson-Fisher RW, Redman S, Gillespie WJ. Environmental hazards in the homes of older people. Age Ageing 1997;26:195-202.

44. Wu H, Lu N. Informal care and health behaviors among elderly people with chronic diseases. J Health Popul Nutr 2017;36:40.

45. Kehusmaa S, Autti-Rämö I, Helenius H, Rissanen P. Does informal care reduce public care expenditure on elderly care? Estimates based on Finland's Age Study. BMC Health Serv Res 2013;13:317.

46. Ludwick R, Silva MC. Ethical challenges in the care of elderly persons. Online J Issues Nurs 2004;9:14. 